Filtering Speed in a Continental European Reorganization Procedure

Nico Dewaelheyns and Cynthia Van Hulle

DEPARTMENT OF ACCOUNTANCY, FINANCE AND INSURANCE (AFI) 


\title{
Filtering Speed in a Continental European Reorganization Procedure
}

\author{
Nico Dewaelheyns a,b,* \\ Cynthia Van Hulle ${ }^{\text {a }}$ \\ ${ }^{a}$ K.U.Leuven, Faculty of Business and Economics, \\ Department of Accountancy, Finance and Insurance (Research Centre Finance), Naamsestraat 69, 3000 Leuven, Belgium \\ ${ }^{\mathrm{b}}$ Lessius University College, Department of Business Studies, Korte Nieuwstraat 33, 2000 Antwerp, Belgium \\ ${ }^{*}$ Corresponding author: e-mail: nico.dewaelheyns@econ.kuleuven.be; tel. +32 16 326766; fax +32 16326732
}

Revised Version: June 2008

\begin{abstract}
Recent studies of U.S. Chapter 11 show it to be a relatively efficient procedure. We examine reorganization cases in a Continental European, creditor-oriented bankruptcy system, viz. Belgium, and report very different findings. Using hazard and cure regression models to determine what drives the length of time spent in reorganizations, we find evidence suggesting that courts have little impact on the screening and filtering process. In fact, virtually all drivers of procedure length prove to have the opposite sign of what one would expect if the procedure would efficiently realise its goals. Instead, the procedure appears to be mainly creditor driven.
\end{abstract}

JEL-Classification codes: G33, K20

Keywords: reorganization, bankruptcy, hazard models, filtering speed

Acknowledgements: We would like to thank an anonymous referee, Marco Becht, Marc Deloof, Dirk Heremans, Frederiek Schoubben and Linda Van de Gucht for useful comments and suggestions and Graydon Belgium for providing additional information. 


\section{Introduction}

During the last two decades, many European countries (including, for instance, the United Kingdom, France, Germany, Italy, Finland and Sweden) have thoroughly reformed their bankruptcy legislation. In most cases the guiding principle of the reform was to change a liquidation based procedure into a more flexible system that encourages corporate reorganization and preserves employment as much as possible. Typically legislators have hoped to achieve this by introducing or reinforcing a U.S. Chapter 11-type formal reorganization procedure. The ultimate goal of this process is to save companies that are financially distressed but economically viable. This implies the bankruptcy system should function as a filtering device. In the case of perfect filtering, efficient companies would always be reorganized and inefficient firms would be liquidated (White, 1994). In practice, asymmetric information causes imperfect filtering, so that dual chapter bankruptcy systems continuously trade-off Type I errors (allowing inefficient firms to continue operations in the reorganization procedure) against Type II errors (closing down viable companies in liquidation).

Critics of Chapter 11-type reorganization procedures argue that the judicial system often allows companies which are manifestly unviable, to remain protected from creditors and market forces, thereby inducing substantial costs (cf. Denis and Rodgers, 2007; see Branch, 2002 for an overview of bankruptcy costs). In some cases, the process appears to be dominated by creditors seeking to extract rents (Ayotte and Morrison, 2008), while courts - which are often underfunded and lacking in economic expertise - are biased towards keeping companies that should be liquidated alive (Morrison, 2007). This negative view of reorganization is supported by studies of Chapter 11's key statistics. Specifically, during the 1980s virtually all quoted U.S. companies that went into bankruptcy filed for Chapter 11 reorganization with success rates of up to $86 \%$ (Weiss, 1990). During the last decade however, the Chapter 11 
procedure seems to have increasingly turned into a mechanism to sell assets or to formalize a pre-negotiated take-over or merger. According to Baird and Rasmussen $(2002,2003)$ the percentage of large companies that successfully emerged from Chapter 11 has dropped to just $24 \%$ in 2002 , while the overall use of the Chapter 11 reorganization procedure has fallen by half compared to the 1980s. Evidence for small businesses is worse, but here overall reorganization success rates have always been low (see White, 1996 for a survey).

Still, not all evidence is unsupportive of reorganizations. Some theoretical models show that the design of the bankruptcy law can enhance efficiency (Gertner and Scharfstein, 1991; Kahl, 2002) while Chapter 11 can be efficient in filtering out unviable firms (Mooradian, 1994). Moreover, a number of recent empirical studies - of both large and small companies show that Chapter 11 reorganizations are not as expensive as is often assumed, and that the screening system does allow a substantial number of firms to successfully emerge in a rational and relatively fast way (Bris et al., 2006; Denis and Rodgers, 2007; Morrison, 2007).

The functioning of European reorganization procedures may be worse than that of Chapter 11. The civil law bankruptcy systems in Continental Europe are more creditor-oriented than the debtor-friendly common law systems, and may thus be biased towards liquidation (see Brouwer, 2006 for a comparative study). Although international comparison of statistics is difficult, the use of reorganization procedures and their success rates across several European countries appear to be substantially lower than in the U.S. (Couwenberg, 2001). This may not be surprising, as recent theoretical research on bankruptcy design and efficiency has shown that in countries where informal reorganizations are well developed - i.e. in bank-based systems which dominate in Continental Europe - a court-controlled reorganization procedure is not necessarily beneficial (e.g. Berkovitch and Israel, 1999; Hege, 2003). 
This paper contributes to the limited empirical evidence on the functioning and the screening efficiency of European reorganization procedures. Specifically, we examine the length of time spent in reorganizations under the 1997 Belgian bankruptcy legislation, which is one of the most recently introduced procedures within a typical bank and small business dominated financial system. The time spent in a procedure is one of the literature's most popular proxies for bankruptcy costs (see e.g. Franks and Torous, 1989; Tashjian et al., 1996; Helwege, 1999), as both direct and indirect costs are likely to be closely related to the procedure's duration (Bandopadhyaya, 1994). Therefore, a growing number of empirical papers examine the determinants of procedure duration with hazard techniques. Several authors use Helwege's (1999) sample of stock exchange quoted Chapter 11 firms (Li, 1999; Orbe et al., 2002; Denis and Rodgers, 2007). By contrast, Bris et al. (2006) and Morrison (2007) collect Chapter 11 case data from bankruptcy courts in one or two U.S. states or judicial districts, which implies their samples predominantly consist of non-exchange quoted small businesses.

Our paper is among the first to study the length of time spent in procedures outside the U.S.'s market-based and debtor-friendly financial system (another recent example is Leyman et al., 2008). We use a unique data set of all limited liability stock corporations $(N V / S A)^{1}$ that filed for reorganization (gerechtelijk akkoord/concordat judiciaire) between 1998 and 2003 in all of Belgium's 27 judicial districts. As a result our data set is relatively large as compared to earlier empirical studies. Although the vast majority (98.7\%) of our sample companies is non-

\footnotetext{
${ }^{1}$ In Belgium, there are two dominant types of limited liability companies: partnerships (BVBA/SPRL) and stock corporations (NV/SA). Partnerships are private companies with low capital requirements (minimum capital of 18,550 EUR, of which only 6,200 EUR needs to be available at formation) which are managed by one or more officially appointed managers, usually partners. Although partnerships are allowed to file for a reorganization procedure, their size makes this unlikely: only about $1 \%$ of total partnership bankruptcy cases are filed under the reorganization code, with extremely low success rates. Stock corporations have higher capital and governance requirements. A minimum of 61,500 EUR needs to be available at the date of incorporation. These firms are managed by a board of directors with at least three members. Shares can be registered or anonymous, and are freely transferable.
} 
exchange quoted, all Belgian stock corporations are subject to strict governance rules and financial statement filing requirements. We can therefore enhance our data set with detailed accounting and ownership information. This allows us to consider potential determinants of procedure length which have so far not been examined in the literature, but which could have an important impact: whether or not the filing company belongs to a business group ${ }^{2}$, general indicators of the financial health of the filing company and the business group it belongs to (in casu, Altman Z"-scores), and several interaction terms to better distinguish between competing hypotheses. Moreover, our main focus is on cases which are transferred to liquidation bankruptcy, because this allows testing more directly for a link between efficiency and speed of the screening process, procedure length and costs of bankruptcy. An efficient system should be able to identify and terminate cases that eventually liquidate as quickly as possible to minimize dissipative costs of reorganization. Morrison (2007) also argues that the costs of reorganization during the duration of the procedure are expected to be highest for unsuccessful cases: for companies that survive, a longer duration only entails higher administrative (i.e. direct) costs; for companies that are liquidated, a longer case duration is likely to result in both higher direct costs and higher indirect costs as the firm's assets could have been redeployed more productively by liquidating. However, as an extension to our analysis, we also estimate cure models that include all cases, regardless of their outcome (i.e. liquidation bankruptcies, voluntary liquidations and successful going concern reorganizations).

Previewing our main results, we find that - in line with theoretical expectations and evidence from other countries - the Belgian reorganization procedure has very low success and survival rates. More importantly, however, we find very little or no evidence of efficient

\footnotetext{
${ }^{2}$ Many (even large) firms are tied together through ownership to form a business group. Especially in Continental Europe, South East Asia and several emerging market regions this group organizational form is important. For instance, $32.4 \%$ of the 100,000 largest companies in terms of total revenue in the euro-zone have group ties (Bureau Van Dijk EP's AMADEUS database, version September 2006).
} 
screening by the courts. Contrary to results for U.S. Chapter 11, we find no links between company level characteristics such as size, liquidity or profitability and the length of time that an unsuccessful reorganization procedure is allowed to continue. The overall financial health proxy is even negatively related to procedure length, i.e. the worse a company's financial health, the longer it stays -wrongfully - protected. The determinants that do turn out to be important (asset specificity, group membership, uncertainty, secured debt and industry conditions) indicate creditor or owner control of the system, rather than court induced filtering.

The remainder of the paper is structured as follows: Section II includes an overview of the Belgian reorganization procedure's design and general performance. Section III discusses the potential determinants of procedure length. The data are described in Section IV. Section V contains some methodological comments and Section VI reports the empirical results. Section VII concludes and discusses some policy implications.

\section{The Belgian 1997 Reorganization Procedure}

Belgium introduced new bankruptcy legislation in $1997^{3}$, to replace the existing Code from 1853. In line with international best practice recommendations ${ }^{4}$, the new Code includes a number of mechanisms to favour reorganization and firm survival within the insolvency system. One of the most important of these mechanisms - at least in theory - is the reform of

\footnotetext{
3 The Bankruptcy Law of August 8, 1997 and the Law on the Reorganization Procedure of July 17, 1997. Both came into effect on January 1, 1998. Some minor legal-technical issues were resolved by the Law of September 4, 2002 (effective as of October 1, 2002).

${ }^{4}$ Best practice recommendations are listed by, for instance, the European Commission (EC, 2003) and the World Bank (World Bank, 2001).
} 
the formal reorganization procedure..$^{5}$ In this Section, we give a brief overview of its main rules, and some key statistics on its functioning during the first six years of its existence. ${ }^{6}$

The new procedure has many elements in common with well-known foreign reorganization procedures (including U.S. Chapter 11, the French 'Redressement Judiciaire', and the British Administration or Voluntary Arrangement procedures; see e.g. Kaiser, 1996). Only the firm's management can decide whether or not to file for protection under the reorganization procedure (i.e. only debtor-initiation is possible). In some cases the Public Prosecutor's Office can initiate, although the firm's management still has to do the actual filing. After the filing, the court has fifteen days to judge to what extent the restructuring of the company's debts is feasible. Moreover, a company's activities should be intrinsically profitable, it should have going concern potential, and there should not be any indication of fraudulent intentions. Any creditor has the right to be heard by the court before a company's application for protection is accepted or denied. If a company is allowed to enter the reorganization procedure, it receives temporary protection from creditors of up to six months (which can be prolonged to nine months). The court appoints an administrator who assists the management in drafting a reorganization plan and who needs to authorize certain decisions and payments necessary for the continuation of the company's activities. The exact responsibilities of the administrator are set by the court on a case-specific basis. The court's ruling is published in the official State Bulletin (Belgisch Staatsblad/Moniteur Belge) and in the local press. All creditors and other interested parties have full access to the case files. Court protection establishes a stay on the execution of all debt-holders' claims (including those of secured and other senior creditor classes), but it does not stop the payment of interests on existing debt. The design of a

\footnotetext{
${ }^{5}$ Although a reorganization procedure exists since 1887 and was updated in 1946, in practice it had been in disuse for decades.

${ }^{6}$ See Dewaelheyns and Van Hulle (2008) for a more detailed analysis of the 1997 legal reform and its potential economic consequences.
} 
reorganization plan is the exclusive right of the management and the administrator, and the plan has to be submitted to court before the end of the temporary protection period. A reorganization plan consists of a detailed analysis of the company's condition, proposals to ensure the company's survival and repayment schedules for all creditors. All creditors affected by the plan can vote in a general assembly of creditors, in which each creditor has one vote, regardless of the size of the claim or the claim's priority. The approval of the plan requires a simple majority of votes, although these votes also need to represent a majority of the total amount of debts outstanding. The approval of the creditors is a necessary but not sufficient condition for the court's confirmation of the plan: the court can reject the plan, even if the majority of the creditors are in favour of it. If the court confirms the reorganization plan, the company enters a protection period of typically two years (which can be prolonged to three years) during which the plan is implemented. Creditors who oppose the plan are subjected to it after the formal confirmation by the court.

However, several classes of senior claimants, including mortgage-holders (i.e. banks), suppliers with retention of title rights on delivered goods and the tax administration need to approve the reorganization plan individually. Strictly speaking, an individual secured creditor cannot veto the confirmation of a plan if the majority of creditors and the court have given their approval. However, a secured creditor that has not approved the plan is not subjected to the plan's conditions after the reorganization procedure has ended. In other words, non-approving secured creditors can execute their claims for the full amount as soon as the company is no longer protected by the court. In practice, this implies that if an important secured creditor does not want to support the plan, the company's long term survival chances are virtually zero, which also lowers the incentives of all other creditors to accept a reduction of their claims under the reorganization plan. As there is no feasible way to bypass the secured creditors' de 
facto hold-up rights (e.g. a cram down procedure), the administrator and the firm's management/shareholders need to convince secured creditors to support reorganization in the early stages of the procedure. The power of unsecured creditors is much smaller: a plan can be confirmed by the court and enforced against the will of some of the unsecured creditors. Contrary to the case of secured creditors, unsecured creditors who vote against the reorganization plan do not have the right to exercise their full claims after the procedure has ended. They do have the right to file a request for modification of a plan if he/she can show that the execution of this plan may cause him/her financial difficulties. However, plan modifications that influence the position of creditors have to be approved by the general assembly of creditors under the same rules as for the original plan (with the same advantages for secured creditors), so this is unlikely to be very helpful. A final option (which is also open to secured creditors, the administrator or management) is to request termination of the reorganization procedure if it can be shown that the terms of the plan are not being met or will be impossible to meet in the future. If the court accepts this request, the reorganization procedure is ended and the stay on creditors' action against the company is removed. This almost invariably leads to a liquidation-

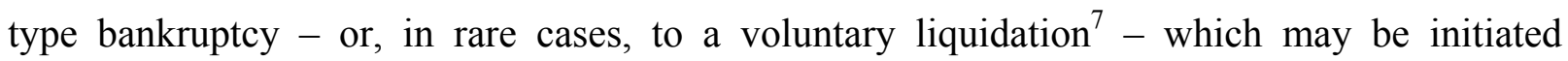
immediately, even during the court session concerning termination of the reorganization procedure. In a liquidation-type bankruptcy the recovery rate of unsecured debt holders is expected to be extremely low, hence they have little incentive to prefer this scenario.

Some initial indications on the reorganization procedure's functioning are given in Table 1. Using data from the official State Bulletin (see Section IV for more information on

\footnotetext{
${ }^{7}$ Voluntary liquidation procedures can be an alternative for liquidation-type bankruptcies, but not in all cases. In some voluntary liquidations all (or almost all) creditors of the liquidating company are paid in full, which implies that the liquidation value of the company's assets is larger than that of its liabilities. In these cases, there is no real default. Insolvent companies can use the voluntary liquidation procedure as an alternative for bankruptcy (deficitaire vereffening) only if strict conditions are met. For instance, all creditors have to approve the liquidation and have the right to appeal for bankruptcy if they can show that this would improve their recovery chances. If they feel that the procedure is only used to avoid bankruptcy, the Commercial Court can terminate the voluntary liquidation and transfer the company to the bankruptcy procedure.
} 
data collection), it shows some key statistics. Panel A of Table 1 reports the outcome of all reorganization cases of limited liability stock corporations which were initiated in the first six years after the new procedure came into effect (1998-2003). Next to these 365 companies that were allowed into the procedure, a small number of firms filed for reorganization but were turned down by the court: the State Bulletin records only 24 cases for which reorganization was rejected and a liquidation-type bankruptcy procedure was started instead. Hence the pre-entry screening of the reorganization procedure - which is quite strict in e.g. Japan (Eisenberg and Tagashira, 1994; Helwege and Packer, 2003) or Sweden (Sundgren, 1998) - appears to be very limited in Belgium.

Table 1 about here

$* * * * * * * * * * * * * * * * * * *$

The most striking observation in Panel 1 is that 260 out of 329 completed cases $(79.0 \%)$ have ended up in the liquidation-type bankruptcy procedure. For comparison, Couwenberg (2001) reports liquidation rates in reorganization of $46 \%$ for the UK and $72 \%$ for France. ${ }^{8}$ Only $12.2 \%$ of the completed cases exits the procedure as going concern, which is extremely low by any standard.

Panel B of Table 1 reports statistics on the duration of all completed reorganization cases during our sample period. The average time spent in the reorganization procedure is 12.3 months (median 7.6 months). A company exiting as a going concern takes 32.1 months on average to complete the procedure, with a minimum of 10.3 months and a maximum of more than 4 years. The same degree of disparity can also be found for cases that end up in liquidation-type bankruptcy: the average is 9.4 months, but individual case lengths vary from a

\footnotetext{
${ }^{8}$ It should be mentioned that comparison across countries is difficult because of the lack of uniformity in sample size, average company size, sampling period, country specific legal differences, etc.
} 
few weeks to more than 51 months. Hence some companies can linger for several years in reorganization protection before they are liquidated. The average duration of the Belgian procedure does not compare favourably to those reported in earlier studies: in the sample of quoted companies used by Li (1999) and Orbe et al. (2002), the average time to (successful) emergence is about 20 months. Morrison (2007) documents that more than $75 \%$ of the unsuccessful small business Chapter 11 cases in his sample are shut down in less than 5 months and $94 \%$ in less than 9 months. The reorganization cases in the sample of Bris et al. (2006) which are converted to Chapter 7 stay in Chapter 11 for 6.4 months on average. It should be remarked that the longer procedure length for Belgium could be partly due to the existence and length of the temporary protection period during which the debtor and the administrator can draw up a plan. This makes it unlikely for a procedure to be terminated during the first months as is often the case in the U.S.

\section{Determinants of procedure length}

The existing literature suggests that the length of time spent in a reorganization procedure is determined by both company-specific and external information, which includes ownership data, industry-specific and court-specific characteristics. The description of the procedure in the previous Section also shows that the perspectives of the owner (who decides about initiation), the creditors and the court are potentially important. This Section formulates hypotheses concerning the explanatory variables used in the multivariate tests of Section VI that will allow us to gain more insight into the actual role of the different parties. An overview of the variables' definitions is contained in Table 2. 
Size - The relative importance of the direct costs which the formal reorganization procedure typically entails are inversely related to firm size (Branch, 2002; Ravid and Sundgren, 1998), which implies that larger companies, ceteris paribus, should be capable of bearing the costs for a longer period of time. Moreover, from the creditors' (e.g. banks) point of view, the incentive to continue to cooperate with a large firm's reorganization procedure should be higher because larger companies are (a) likely to be clients with a better bank relationship (cf. Rajan, 1992) and (b) the potential gain of cooperation is larger. Finally, assessing the companies' viability may be more complex for larger cases. All of the preceding arguments predict a positive relationship between company size and the length of time spent in the reorganization procedure. On the other hand, judges may be more interested and motivated to handle larger cases (cf. Bris et al., 2006), which would speed up the decision process and could lead to a negative relationship between size and procedure length.

Profitability - A company's current profitability may proxy for future profitability and hence for going concern value (Helwege and Packer, 2003). Therefore one could argue that profitability and the probability of staying in the reorganization procedure should be positively related. By contrast, it should also be easier to find a buyer for more profitable operations, implying a negative relationship between profitability and time spent in reorganization.

Liquidity - Kim and Kim (1999) argue that, ceteris paribus, creditor's incentives to cooperate in reorganization are lower if the company has many assets which can easily be distributed in a liquidation procedure. This logic implies a negative relationship between liquidity and the length of the reorganization procedure. On the other hand, the liquidity ratio could also be regarded as an inverse measure of the severity of the financial difficulties. This latter view would predict a positive relationship. 
Leverage - As the overall level of leverage is an indicator of the severity of the financial difficulties the company faces, it could be hypothesized that filing companies with higher leverage levels are more quickly removed from the reorganization procedure. However, the degree of leverage can also be regarded as a proxy for the complexity of the reorganization problem (cf. Li, 1999), implying the opposite relationship (i.e. it takes longer to assess whether or not more highly levered companies can be reorganized).

Asset specificity - In general, company or industry specific tangible assets (such as machinery) are assumed to be relatively illiquid, i.e. the number of potential buyers is limited so that they are difficult to sell at a fair price during a 'fire sale' (Berger et al., 1996). The reorganization procedure gives companies the opportunity to continue to use these specific assets, which preserves going concern value (Baird and Morrison, 2005). Hence, companies with high specific asset levels should be more successful in convincing creditors to keep supporting reorganization, in view of their low liquidation value. This could lead to a positive relationship between asset specificity and the duration of the procedure.

Financial health - As already mentioned, the profitability, liquidity and leverage variables discussed above can also be interpreted as proxies for the severity of the financial problems. However, in the accounting and finance literature, financial health is often measured by a score based on a failure prediction model. The models developed by Altman (1968) and Ohlson (1980) are among the most influential examples of these types of models. The Z"-score which is used in this paper, an adjusted version of the Altman (1968) Z-score developed for non-stock exchange quoted companies (Altman, 1993), can be regarded as an encompassing measure containing the relevant information of the individual variables within the bankruptcy prediction 
model. The worse the financial health of the company, ceteris paribus, the lower the chances of recovery are likely to be. A procedure with effective filtering should be able to remove the companies with the worst financial situation relatively quickly. If this is the case, the time spent in reorganization before liquidation should be positively related to the financial health proxy, as higher Z"-scores indicate stronger financial health. On the other hand, if the procedure is used as a mechanism to sell companies (or parts of companies), the opposite relationship could hold as firms in better financial health should be easier to sell.

Uncertainty - The larger the degree of uncertainty about the value (or potential profitability) of the filing company, the more difficult it may be for the court to assess the company's viability, and hence the longer it should take to exercise the option to shut down and liquidate (Morrison, 2007). On the other hand, creditors - especially secured creditors such as banks - may be more in favour of fast liquidation if uncertainty is high, thus eliminating the risk of future losses. As a proxy for uncertainty, we compute the average standard deviation of the operating profit margin within the industry over the last three fiscal years before the filing date.

Secured debt - As discussed above, secured creditors may have incentives to push for liquidation. Bergström et al. (2002) show that well-secured creditors are more likely to oppose reorganization of Finnish SMEs. Ayotte and Morrison (2008) find evidence of a secured creditor-driven fire-sale bias in large U.S. Chapter 11 cases: the presence of secured creditors substantially decreases the probability of a traditional reorganization, but increases the likelihood of a quick sale. We therefore expect the secured debt ratio (defined as secured debt to total assets) to be negatively related to procedure length. 
Industry conditions - Several authors (including Maksimovic and Phillips, 1998; Routledge and Gadenne, 2000 and Campbell, 1996) suggest that the economic conditions in a reorganizing company's industry could influence its survival chances. Companies in growing, highly profitable industries may be able to continue operations for a longer time if courts allow these firms more time to reorganize. However, it is also possible that creditors are less prone to liquidate early as they are less likely to lose value by postponing liquidation if the business climate is beneficial. By contrast, Shleifer and Vishny (1992) argue that the liquidation value of assets in a booming industry is higher because of a larger number of potential buyers with sufficient cash flows. If this latter effect dominates, companies in stronger industries may be liquidated sooner than firms with activities in struggling industries. We include the average sales growth and average operating performance margin of the reorganizing company's industry as proxies for the state of the industry. ${ }^{9}$

Business group membership - In many Continental European countries, legally independent companies are often tied together through pyramidal ownership structures or crossparticipations (La Porta et al., 1999). Because each group member company has separate limited liability, each member can individually file for bankruptcy, while the group's other activities remain unharmed (cf. Bianco and Nicodano, 2006). Creditors, including banks, may have stronger incentives to cooperate in a restructuring effort of a business group member as compared to the reorganization of a stand-alone company if they value their relationship to the group as a whole. This would lead to a positive link between group membership and time spent in reorganization. Alternatively, it can also be hypothesized that business groups are able to use their networks to find potential buyers for the member company's assets (within or outside of the group structure) more quickly than stand-alone companies, resulting in a negative

\footnotetext{
${ }^{9}$ Remaining industry effects will be controlled for by dummies.
} 
relationship between procedure duration and group membership. Groups may also wish to solve the problem quickly to limit the damage to their reputation.

However, the preceding arguments implicitly presume that the group as a whole is in reasonably good financial health. In fact, if the group's financial condition is weak, creditors' opportunities for future cooperation dwindle, while moral hazard problems and incentives for the group to shift resources away from the subsidiary mount. Creditors anticipating such behaviour may then favour early liquidation. By contrast, if the use of networks is an important force driving procedure duration, financially weak groups are likely less able to find potential buyers quickly. In other words, the group's capacity to shorten the procedure would be smaller. Analogous to the filing company financial health variable, we use the Altman Z"-score of the most important group member company ${ }^{10}$ as a proxy for group financial health.

Court specific variables - The fact that bankruptcy courts have a considerable amount of leeway in making key procedure decisions can give rise to differences in outcome from district to district. It seems inevitable that some courts are stricter than others (cf. Sundgren, 1998). Evans (2003) empirically confirms that judges' discretionary actions indeed have a significant effect on the outcome of U.S. Chapter 11 procedures. The court's stance could, for instance, depend on the local socio-economic environment, i.e. in high unemployment areas the willingness to consider reorganization might be higher. The size of Belgium's judicial districts also varies widely, implying that courts in areas with limited economic activity have very little experience in handling reorganization cases, while others deal with these issues as a matter of routine. As a downside, these experienced courts may have too many cases to handle relative to

\footnotetext{
${ }^{10}$ Following Dewaelheyns and Van Hulle (2006) we use the financial statements of the sample company's ultimate corporate owner to compute the group financial health proxy. If the ultimate corporate owner is a financial holding company (i.e. a control vehicle without substantial sales of its own) we use the financial statements of the group member company with the largest amount of sales instead.
} 
their often limited resources. All of the country's 27 judicial districts handled reorganization cases during our sample period, but the number of cases ranges from 1 (Ypres and Neufchâteau) to 50 (Antwerp). To control for these issues, we include two variables. The first one (Cases per judge) is a measure of judicial experience, proxied by the average number of reorganization cases in the district per full-time bankruptcy judge during our sample period. The second is a dummy variable (Region) has a value of 1 if the court is situated in an area with an average unemployment rate during the sample period higher than the national median (10 districts, all situated in the southern part of the country).

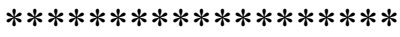

Table 2 about here $* * * * * * * * * * * * * * * * * * *$

\section{Data and sample}

All main court decisions in a reorganization case (e.g. start/end/extension of preliminary protection period, plan confirmation, end/extension of plan protection period) are published in the official State Bulletin (Belgisch Staatsblad/Moniteur Belge). The State Bulletin also lists in which judicial district a case has been filed, and reports general information on the filing company and the court appointed administrator. Using the online database of the Ministry of Justice we compile a nationwide list of all reorganization cases involving limited liability stock corporations $(\mathrm{NV} / \mathrm{SA})^{11}$ initiated between the introduction date of the procedure (Jan 1st, 1998) and the end of 2003. This results in a total of 365 cases. We first focus on companies which end up in the liquidation-type bankruptcy procedure, which is by far the most likely outcome (260 cases out of 365 , cf. Table 1). As mentioned above, looking solely at these cases allows for

\footnotetext{
${ }^{11}$ See footnote 1.
} 
clean testing of the efficiency of the system, as an efficient system should be able to quickly identify and terminate unviable cases.

Financial statement data on the companies involved and the industries in which they are active are obtained from private data provider Bureau Van Dijk's BelFirst database. Following common practice, we use data from the last financial statement the company filed before the initial request for reorganization or bankruptcy protection. To ensure a sufficient level of data quality, we exclude companies for which the time period between the financial statement date and the judicial filing date is longer than 18 months, and several types of financial or holding companies. Within this sample, following Helwege (1999) and Bris et al. (2006), we only identify unique cases. In our setting this implies we have to remove several blocks of closely related companies that file for reorganization bankruptcy together. Including these cases could give rise to two problems. Firstly, the duration and the outcome of the reorganization procedures is the same for all companies in a certain block, which would lead to clustering of the dependent variable. Secondly, using individual company financial statement data as explanatory variables is likely to be inappropriate as courts appear to judge these blocks of cases as one. As a result, we end up with a testable sample of 127 unique reorganization cases which are transferred to the liquidation-type bankruptcy procedure. ${ }^{12}$ To the best of our knowledge, this is the largest sample of unsuccessful reorganization cases thus far examined in the literature. ${ }^{13}$

\footnotetext{
${ }^{12}$ Of these 127 companies only two are stock-exchange quoted. As the treatment of quoted firms may be somewhat different because of, for instance, lower information asymmetry, a higher level of public attention, more dispersed ownership, etc., we deleted these two observations from the data set as a robustness check. All results and findings remain unchanged.

${ }^{13}$ For comparison, the sample of Bris et al. (2006) contains 42 Chapter 11 cases which are converted to Chapter 7 , the sample of Morrison (2007) contains 19 of such cases plus 40 dismissals (i.e. 59 shut downs in total); in Denis and Rodgers (2007)'s sample 37 Chapter 11 cases end up in liquidation; in Leyman et al. (2008), 119 cases fail.
} 
Next, we extend our sample to also include companies that do not end up in liquidation bankruptcy to get a broader picture of the procedure. Collecting information for all cases that meet the data requirements listed above leads to an additional 13 testable observations for companies that went into voluntary liquidation (cf. footnote 7) and 18 testable observations for companies that successfully reorganized as a going concern, extending the total sample to 158 cases. For all of these companies, we compute the variables discussed in the previous Section (see Table 2 for definitions).

Table 3 contains information on the sample's size and industry distribution and summary statistics on all explanatory variables. Panel A reports that the mean total asset size of our sample companies is 4.5 million euros (median of 1.3 million), which is relatively large for a sample of predominantly non-exchange quoted companies. ${ }^{14} \mathrm{~A}$ closer view at the size distribution shows that almost half of our sample companies have total assets of 0.5 to 2.5 million euros. $20.9 \%$ of all companies are micro firms, while only $7.6 \%$ (i.e. 12 companies) have total assets in excess of 10 million euros. The sample's industry composition in Table 3 Panel B shows that more than two thirds of all companies are active in manufacturing, construction and trade. This is consistent with the view that a formal reorganization procedure is usually most applicable to companies in traditional industries (cf. Baird and Rasmussen, 2003). Finally, Panel C reports the mean, median and standard deviations of all continuous explanatory variables and the mean of all dummy variables. ${ }^{15}$ It can be observed that the companies filing for reorganization, on average, are in very poor financial health. Not unexpectedly for companies applying for formal reorganization protection, they are generating losses (average profitability ratio of -0.14) and have liquidity problems (average quick ratio

\footnotetext{
${ }^{14}$ For comparison, the average total asset size in Morrison's (2007) small business sample is 0.66 million dollars (median of 0.11 million); the average of Bris et al.'s (2007) small and large business sample is 19.8 million dollars (median of 1.2 million).

${ }^{15}$ The continuous variables were winsorized at 5 and $95 \%$ to reduce the impact of outliers.
} 
well below 1). Furthermore they are very highly levered. The average total liabilities ratio is 1.05, which implies that the average shareholders' equity is negative. The financial health proxy (based on an Altman Z"-score) also points to very severe difficulties, making recovery as a going concern highly unlikely. ${ }^{16}$ This confirms the practitioners' view that many companies wait too long before filing for reorganization protection, for instance because of negative reputation effects caused by the so-called stigma of failure which is present throughout the European Union (European Commission, 2002; Brouwer, 2006). The bad condition of the filing companies, as indicated by the univariate statistics, again points to lack of pre-entry screening by the courts. Interestingly, for the companies with business group ties (39 out of 158 cases), it can be observed that the group financial health proxy indicates problems as well, although to a lesser extent than at the level of the filing company itself. This is consistent with empirical evidence from Dewaelheyns and Van Hulle (2006) who find that Belgian business groups tend to support their struggling subsidiaries and only let them file for reorganization or bankruptcy if the group's financial situation forces it to do so.

$* * * * * * * * * * * * * * * * * * *$

Table 3 about here

$* * * * * * * * * * * * * * * * * * *$

\section{Methodology}

One of the most commonly used techniques in the literature on bankruptcy procedure duration are accelerated failure time regression models (see Kiefer, 1988 for a discussion of the modeling of economic duration data). The dependent variable in these types of models is the natural logarithm of the number of days or months spent in the procedure. Following, for

\footnotetext{
${ }^{16}$ The median Z"-score in our sample is -2.18 , while Altman (1993) classifies scores of below 1.10 as indicating severe problems.
} 
instance, Bandopadhyaya (1994) and Denis and Rodgers (2007) we assume a Weibull distribution for the baseline hazard function $h_{0}{ }^{17}$ :

$h_{0}(t)=\lambda \gamma t^{\lambda-1}$

where $t=$ time, $\lambda=$ shape parameter and $\gamma=$ scale parameter (Hosmer and Lemeshow, 1999).

The accelerated failure time form of equation (1) can be written as:

$h(t, x, \beta, \lambda)=\lambda t^{\lambda-1} e^{-\lambda\left(\beta_{0}+\beta_{l} x_{1}+\beta_{2} x_{2}+\ldots\right)}$

where $x=$ covariates, $\beta=$ coefficients estimated in the accelerated failure time model.

In our context, $h(t)$ is the conditional probability that the reorganizing company is transferred to the liquidation-type bankruptcy procedure given that it has stayed in the reorganization procedure up to time $t$. Intuitively, equation (2) links the hazard of being removed from the reorganization procedure to the values of the covariates $(x)$. SAS transforms equation (2) to link the time spent in the procedure with the covariates. The parameters are estimated by maximum likelihood using a Newton-Raphson algorithm. Note that coefficients in this type of accelerated failure time can be interpreted directly, i.e. a positive $\beta$ points to a longer period of time spent (and thus to a lower hazard rate), and vice versa. The survivorship function $S$ corresponding to (2) is:

$S(t, x, \beta, \lambda)=\exp \left\{-t^{\lambda} \exp \left[-\lambda\left(\beta_{0}+\beta_{1} x_{1}+\beta_{2} x_{2}+\ldots\right)\right]\right\}$

The use of standard accelerated failure time models is only appropriate if all observations experience the event (in our case, end up in liquidation). If data on all available cases is used, we estimate logistic-Weibull mixture cure models that simultaneously model the

\footnotetext{
${ }^{17}$ As a robustness check, we reestimate all models assuming an exponential, log-logistic or gamma distribution for the baseline hazard function. Results are very similar.
} 
probability that a company is not successful and the length of time spent in the procedure, implementing Corbière and Joly's (2007) macro for SAS. In other words, this takes into account that the companies that eventually survived as going concerns were at risk of failing and going into liquidation as long as they were in the reorganization procedure (Morrison, 2007). As a result, the unconditional survival function of the mixture cure model for the entire population is:

$\mathrm{S}(t \mid x, z)=\pi(z) \mathrm{S}(t \mid \mathrm{U}=1, x)+1-\pi(z)$

where $\pi(z)=$ probability that the procedure will be unsuccessful, given a covariate vector $(z)$ and $\mathrm{S}(t \mid \mathrm{U}=1, x)=$ the survival function for unsuccessful cases given a covariate vector $(x)$.

\section{Tests and results}

The results of Weibull accelerated failure time models for the length of cases ending up in liquidation bankruptcy are reported in Table 4. The first model (model A) only contains the basic company-specific variables which can be computed from the firm's financial statements (size, profitability, liquidity, leverage and asset specificity). Although in theory each of these variables could be related to a company's survival chances and thus to the court's decisions (see Section III), it turns out that they are only very weakly related to the time spent before transfer to the liquidation procedure. The first four of these variables are not significant. ${ }^{18}$ By

\footnotetext{
${ }^{18}$ W.r.t. profitability, our results differ from those of Leyman et al. (2008), who do find a significant positive relationship between profitability and case duration for a sample of 44 micro and small sized Belgian companies, which is consistent with efficient filtering: the least profitable companies are removed first. One possible explanation for this difference could be the fact that Leyman et al. (2008) only study cases in the postconfirmation stage of the procedure, while we also include those cases that do not succeed in drafting a confirmed reorganization plan (which is the case for the vast majority of all started reorganization procedures). Moreover, the average size of the companies in Leyman et al.'s (2008) sample is substantially smaller than that of our sample companies. It could be hypothesized that creditors are only interested in exercising control over a procedure if their potential gains (or their potential losses if they allow reorganization to continue) are large enough to warrant the effort. It is therefore possible that the reorganization procedure is less creditor-driven in micro sized firms and therefore exhibits better filtering performance - than in small, median and large sized cases. As a robustness check we run a number of additional models on a sub-sample of post-confirmation cases only (not reported,
} 
contrast, asset specificity is significant in all models in Tables 4 and 5 . Its positive sign is as expected: companies with relatively many specific assets, which are difficult to liquidate at a good price, stay in reorganization longer. Leverage is significant at the $10 \%$ level in some of the models, with a positive sign. If Leverage is interpreted as a proxy for case complexity, the positive sign is as expected in the literature: more complex cases need more time to be assessed. If Leverage is seen as a proxy for the severity of financial difficulties, the positive sign is unexpected: companies in worse financial health remain in the procedure for a longer period of time.

Also note that the shape parameter (larger than 1) indicates that the hazard increases with time. Bandopadhyaya (1994) argues this positive duration dependence in the hazard arises directly from the way reorganization cases are handled: immediately after the filing date all parties involved (judges, administrators and creditors) need time to analyze and assess the company's situation, implying that the hazard of being removed from the procedure is relatively low. As time progresses, and the company needs to formulate or execute a reorganization plan, the probability of exit increases.

$* * * * * * * * * * * * * * * * * * *$

Table 4 about here

$* * * * * * * * * * * * * * * * * * *$

In model $\mathrm{B}$, we add factors which do not directly relate to the financial condition of the company: the group membership variable (Group) ${ }^{19}$, the court specific variables (Cases per

available upon request). Most financial variables (Liquidity, Leverage, Asset specificity and Financial health) are not significantly related to procedure duration, although it should be noted that the power of the models is low due to the small number of observations (35). In one of the models, Profitability is significant at the $10 \%$ level with a positive sign, which is weak evidence indicating that the procedure may be more geared towards continuation as a going concern in the post-confirmation period for our sample of corporations as well.

${ }_{19}$ To avoid multicollinearity problems which could arise from the fact that group member companies differ significantly from stand-alone companies (for instance in terms of size), the group variable used in the models of Tables 4, 5 and 6 is an instrumental variable (the residual of a logistic regression model with the group dummy as 
judge and Region), the industry risk proxy (Uncertainty) and one of the measures of industry conditions (Industry sales growth). Model B' is identical to model B, except for the fact that it includes an alternative industry condition variable (Industry profit margin). Group membership is a highly significant determinant of the length of time spent in an unsuccessful reorganization procedure: ceteris paribus, group member firms are liquidated more quickly than stand-alone companies. The court-specific variables are not significant. Contrary to the findings of Morrison (2007), Uncertainty is highly significant with a negative sign: the higher the degree of uncertainty, the faster the company is liquidated. Morrison (2007) argues that the positive relationship he finds between uncertainty and the procedure length is a strong signal of the rationality of the U.S. Chapter 11 process: judges give cases with high uncertainty the necessary time to prove they can be reorganized. Our findings may indicate that in a bankbased system the stricter stance of the creditors towards uncertain cases dominates, i.e. creditors (banks) may be less supportive of a reorganization procedure if the chances that substantial value may be lost in the future are high. As in practice reorganization is unfeasible without bank support, the court then has little choice but to terminate the procedure.

The industry condition variables, Industry sales growth in model B and Industry profit margin in model B' are both positively related to the length of the procedure, although Industry profit margin is not significant at the $10 \%$ level ( $\mathrm{p}$-value is 0.109 ). The model specification using sales growth therefore has a substantially better fit, as measured by the log likelihood and the likelihood ratio test. To gain more insight into the relationships between these industryspecific variables and the length of the procedure, we interact them with Uncertainty in models $\mathrm{C}$ and $\mathrm{C}^{\prime}$. The interaction terms (Uncertainty*Industry sales growth and Uncertainty*Industry profit margin) are highly significant with a positive sign. This could imply that companies in 
industries with a higher degree of uncertainty are liquidated sooner, but that this effect is less outspoken if the prospects of the industry - proxied by sales growth or profit margin - are good. In other words, courts or creditors are less eager to stop supporting companies with a high degree of uncertainty if the industry outlook is positive. ${ }^{20}$

In model $\mathrm{D}$, we added the secured debt ratio instead of an industry-specific variable. Secured debt is negatively related to procedure length, which is consistent with the view that secured creditors have incentives to push for liquidation as soon as possible. The Uncertainty*Secured debt interaction term in model D' is also significantly negative (at the $10 \%$ level). This implies that the negative impact of Uncertainty on the length of the procedure becomes stronger as the secured debt ratio rises: secured creditors are more likely to prefer liquidation if there is more uncertainty. To further examine the validity of this interpretation, we split up the Uncertainty*Secured debt interaction term using dummy variables expressing whether or not the industry outlook is weak. ${ }^{21}$ Results are reported as model E in Table 5. Uncertainty itself remains highly significantly negative, but the interaction with Secured debt is only significant (at the $1 \%$ level) when the industry outlook is weak (Uncertainty*Secured debt*Weak industry outlook). All of these negative relationships between the secured debt ratio and the time to the end of the reorganization procedure are consistent with a secured-creditor driven sale bias (cf.

\footnotetext{
${ }^{20}$ To ascertain the economic significance and clarify the interpretation of our results, we compute the elasticity for a one unit change in a certain variable in model $\mathrm{C}$, if all other variables would have median values. The elasticities of Size, Profitability and Liquidity are virtually zero (which makes sense, in view of the fact that they are not significant): e.g. an increase of Profitability by 0.01 reduces case duration by about 0.2 days. For the significant variables, the elasticities appear to be economically reasonable: an increase of 0.01 in the leverage ratio increases the duration by 0.9 days; an increase of 0.01 in Asset specificity adds 2.6 days and a shift from non-group affiliated to group-affiliated reduces the procedure length by 64 days. W.r.t. Uncertainty there are two effects: a direct one and an indirect one through the interaction term. Taking both into account, an increase of 0.01 in the uncertainty measure reduces case duration by 12.4 days. An increase of the industry sales growth (which only enters the model via the interaction term) by 0.01 adds 7.0 days to procedure length.

${ }^{21}$ We define industries within the lowest quartile of sales growth of all industries in our sample as having weak industry outlook and those within the upper three quartiles as having normal or strong industry outlook. Robustness checks show that other cut-offs (e.g. 20/80 or 33/66) lead to very comparable results.
} 
Ayotte and Morrison, 2008). ${ }^{22,23}$ The consequences of such a sale bias for the value preservation ability of the Belgian insolvency system are not clear, but are unlikely to be beneficial. One important element could be the question whether or not many companies are sold piecemeal - in which case any remaining going concern value is destroyed - or as a whole - in which case at least some going concern value may be preserved. The Belgian insolvency system does not have a formalized going concern sale comparable to, for instance, a Section 363 sale in the U.S. or a "plan de cession" in France. The State Bulletin therefore does not record whether a bankrupt company is sold piecemeal or as a whole. Still, recent empirical evidence shows that even going concern sales destroy a lot of value compared to companies that successfully reorganize. LoPucki and Doherty (2007) show that recovery rates of Section 363 sales of large publicly traded companies are only $29 \%$ of book value, compared to $75 \%$ for companies that reorganize in the period 2000-2004. They argue this could be due to the fact that bids are often too low because of limited liquidity in the market (often there is only a single bidder) and incentives for managers and professional advisors to support underpriced sales. LoPucki and Doherty also point out that the efficiency of the market for private companies is likely to be even lower, which implies that the loss of value could be even worse for our sample companies. Blazy et al. (2008) compare recovery rates across going concern sales, liquidations and reorganizations for a sample of French SMEs and find (in the period 1995-2005) hardly any difference between recovery rates in going concern sales and piecemeal liquidations, while

\footnotetext{
${ }^{22}$ Even though Secured debt is significant in our analysis, our secured debt ratio is financial statement based and therefore likely to underestimate the true importance of secured debt. It can be expected that the secured debt ratio increases between the date of the last financial statement and the case filing date. Ayotte and Morrison (2008) show that the average secured debt ratio in their sample of large U.S. companies increased from ca. $22 \%$ based on financial statements to almost $38 \%$ based on filing data.

${ }^{23}$ To further explore this issue, we have estimated two additional logit models for the probability of case success. The first one includes the secured debt ratio, which has a negative coefficient, but is not significant. The second model replaces the secured debt ratio by a dummy for the presence of secured debt. This secured debt dummy is significant with a negative sign: companies with secured debt, ceteris paribus, have a lower chance of successfully reorganizing as a going concern. Again - although it is only indirect evidence - this is consistent with the presence of a secured creditor-driven sale bias.
} 
both are much lower than for reorganizations. Unfortunately, there is no systematic collection of recovery data in Belgium, so this issue cannot be further explored empirically.

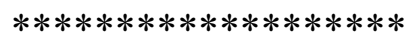

Table 5 about here $* * * * * * * * * * * * * * * * * * *$

In the next models in Table 5, we take a closer look at the impact of industry outlook on the effect of uncertainty by splitting up Uncertainty into Uncertainty*Normal or strong industry outlook and Uncertainty*Weak industry outlook. In model F, both interactions are negatively related to time spent in the procedure but only the latter interaction term is significant: uncertainty only leads to liquidation more quickly if the company is active in an industry with weak prospects.

The next model reported in Table 5 (model G) builds on the model with the best fit so far (model F) but replaces the company-specific variables with the Altman Z"-score for financial distress (Financial health). This variable is significantly negatively related to the procedure length (at the $1 \%$ level), which is in line with the significant positive effect for Leverage found in some of the models, but the opposite of what one would expect in an efficient filtering system: companies in relatively limited distress are liquidated first, while companies with more severe financial difficulties are allowed to stay in the procedure the longest. Again, this suggests an important impact of the creditors on the length of the procedure: if financial distress is extremely high, the creditors' recovery rates are likely to be low and their incentive to allow the reorganization to continue - while hoping for an unlikely recovery - is larger. The judicial system appears to be unable to identify these cases in a timely fashion, which can be interpreted as evidence of a continuation bias in the Belgian reorganization procedure. On the other hand, this result could also be driven by the fact that 
companies in better financial health should be easier to value and sell at an acceptable price, which again points in the direction of a sale bias.

The final model in Table 5, H, takes a closer look at the group membership variable. The fact that Group is significantly negatively related to procedure length in all models could either indicate that business groups may be able to find buyers for the failing company's assets more quickly, or that creditors push for a fast liquidation. To distinguish between the two explanations we add information on the group's financial health. Specifically, we split up the Group dummy according to whether or not the group is financially distressed according to Altman's Z"-score. Both dummies remain significant, with a negative sign. The finding that subsidiaries of non-distressed groups are more quickly removed from the procedure supports the hypothesis that groups use their networks to terminate the problems of their struggling subsidiaries more quickly. The fact that this is also the case for subsidiaries of distressed groups, albeit to a somewhat lesser extent, indicates that groups continue to use the remaining opportunities of their networks and/or that creditors push towards a quick removal from the procedure in order to limit resource shifting and moral hazard problems. In sum, the evidence concerning group ownership is likely to be more informative about the efficiency of business groups' networks than about the reorganization procedure's filtering ability, especially if groups are financially sound. A final point of notice in Table 5 is that the proxy for judicial experience, Cases per judge, is significant (at the 5 or $10 \%$ level) in all models: the more experience the average bankruptcy judge in a certain district has with reorganization cases, the shorter the length of the procedure. This could be due to learning effects, which allow for faster decision making by more experienced judges. 
In the final Table, Table 6, we report results of logit-Weibull cure models for the full sample, i.e. including not only cases ending in liquidation bankrupty, but also those ending in voluntary liquidation or as a reorganized going concern. To limit the dimensions of the Table, only the failure time parts of the models are reported..$^{24}$ The variables included in the models in Table 6 are analogous to those in Table 5. The most important results (w.r.t. Group, Financial health, Uncertainty and the interaction terms with Uncertainty) remain unchanged and are therefore completely robust for the extension of the analysis to all cases. The most striking differences are that Leverage (which, as mentioned above, is borderline significant in Tables 4 and 5) and Asset specificity (which is significant at the 5 or $10 \%$ level in all of the models in Tables 4 and 5) are not significant in the cure models reported in Table 6. This could indicate that leverage (as a proxy for case complexity and/or financial health) and asset specificity are only important in explaining the duration length for non-successful cases, or that the relationship between these variables and case duration is different for successful and unsuccessful cases. In theory, new AFT models could be estimated to examine the determinants of procedure length for successful cases separately. Unfortunately, because of the very low success rates in the Belgian reorganization procedure, our sample only includes 18 successful cases, which are much too few observations to estimate a meaningful AFT model.

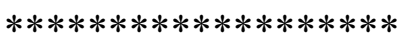

Table 6 about here

$* * * * * * * * * * * * * * * * * * *$

\footnotetext{
${ }^{24}$ In the logit part, only the Size variable is significant in all models: larger companies have a higher probability of being "cured", i.e. being reorganized as going concern.
} 


\section{Concluding remarks}

We consider a unique sample of mostly non-quoted Belgian companies that filed for reorganization between 1998 and 2003. As in other Continental European countries, success rates are very low: almost $80 \%$ of the completed cases end up in liquidation-type bankruptcy, while only $12 \%$ exit as going concern. Moreover, the average length of time spent in the procedure is long as compared to, for instance, cases in U.S. Chapter 11. In general, our results show the procedure does not result in efficient screening and filtering. Virtually all companies in the official records that apply for reorganization are allowed into the procedure, indicating that pre-entry screening is limited. To assess post-entry screening, we estimate hazard regression models of the determinants of time spent in unsuccessful reorganizations and cure models of the determinants of time spent in all reorganization cases. Overall results are not supportive of strong screening and filtering activity by the courts. We find no relationships between company level variables such as size, leverage, profitability and liquidity and time spent in the procedure. We do find evidence suggesting that the creditors' stance towards reorganization is important: ceteris paribus, cases in which creditors most likely benefit from swift liquidation - i.e. companies with few specific assets active in industries subject to high uncertainty - are liquidated more quickly. Especially secured creditors appear to be important, which is not surprising given the strong hold-up rights allowed to them by the procedure. The fact that companies in the best financial health are liquidated first is supportive of a secured creditor-driven sale bias (cf. Ayotte and Morrison, 2008), as these companies are the most likely to be sold quickly for an acceptable price. Moreover, the fact that companies in the worst financial health - i.e. the companies which are the least likely to survive as going concerns are allowed to stay in the procedure for the longest periods of time is consistent with a continuation bias. The filing company's ownership structure matters as well: if the company is 
part of a business group it is liquidated faster. Our evidence supports the notion that this is likely due to the fact that groups can use their networks to find buyers for their subsidiaries' assets more quickly. Overall - analogous to Baird and Rasmussen's $(2002,2003)$ observations concerning Chapter 11 - our findings do not allow us to conclude that the Belgian procedure succeeds as an instrument to reorganize and save companies as going concerns. Instead, our results are consistent with the view that the procedure is often used as a device to sell assets or to formalize a pre-negotiated take-over or merger.

In practice, the low effectiveness and survival rates we document in this paper have damaged the reputation of the reorganization procedure to the extent that its use has dropped to very low levels. The Belgian Government is therefore planning a new reform of the legislation. One of the most important proposed changes is to replace the expensive, but professional administrator by a court official for smaller cases. The findings of this paper indicate that it is unlikely this will have important beneficial effects, as the reduction of direct costs cannot alleviate the problems of creditor control. Arguably, the most straightforward way of increasing success rates would be to reduce the power of creditors (especially secured creditors such as banks; see Brouwer, 2006). However, this could have an important negative impact on the willingness of banks to provide credit to firms in financial distress, which could lead to even fewer distressed companies being saved. Without a solution for this dilemma, the chances of success for any reform of the procedure are low. The theoretical conclusions which can be derived from Berkovitch and Israel (1999) or Hege (2003) may apply to the case of Belgium: informal reorganization and negotiation with creditors is of such paramount importance in a bank-based economy that the introduction of a dual chapter bankruptcy system may even decrease overall efficiency. In other words, it may be preferable to return to a liquidation-only system instead of allowing certain classes of secured creditors or business groups to extract 
rents at the expense of, for instance, unsecured creditors. However, more research into the recovery rates of the liquidation and reorganization procedures for different classes of claimants is needed to empirically confirm or reject this point of view.

\section{References}

Altman, E.I. (1968). Financial ratios, discriminant analysis and the prediction of corporate bankruptcy. Journal of Finance, 23, 589-609.

Altman, E.I. (1993). Corporate financial distress and bankruptcy: a complete guide to predicting and avoiding distress and profiting from bankruptcy, $2^{\text {nd }} e d$. New York: John Wiley and Sons.

Ayotte, K.M. \& Morrison, E.R. (2008). Creditor control and conflict in Chapter 11. Columbia University Center for Law and Economics Studies, Research Paper Series No. 321.

Baird, D.G., \& Morrison, E.R. (2005). Serial entrepreneurs and small business bankruptcies. Columbia Law Review, 105, 2349-2365.

Baird, D.G., \& Rasmussen, R.K. (2002). The end of bankruptcy. Stanford Law Review, 55, 751-790.

Baird, D.G., \& Rasmussen, R.K. (2003). Chapter 11 at twilight. Stanford Law Review, 56, 673700.

Bandopadhyaya, A. (1994). An estimation of the hazard rate of firms under Chapter 11 protection. Review of Economics and Statistics, 76, 346-350.

Berger, P.G., Ofek, E., \& Swary, I. (1996). Investor valuation of the abandonment option. Journal of Financial Economics, 42, 257-287.

Bergström, C., Eisenberg, T., \& Sundgren, S. (2002). Secured debt and the likelihood of reorganization. International Review of Law and Economics, 21, 359-372.

Berkovitch, E., \& Israel, R. (1999). Optimal bankruptcy laws across different economic systems. Review of Financial Studies, 12, 347-377.

Bianco, M., \& Nicodano, G. (2006). Pyramidal groups and debt. European Economic Review, 50, 937-961.

Blazy, R., Chopard, B., Fimayer, A. \& Guigou, J-D. (2007). Financial versus social efficiency of corporate bankruptcy law: the French dilemma? Centre of Research in Finance Luxembourg School of Finance Working Paper 07-02.

Branch, B. (2002). The costs of bankruptcy: a review. International Review of Financial Analysis, 11, 39-57.

Bris, A., Welch, I., \& Zhu, N. (2006). The costs of bankruptcy: Chapter 7 liquidation versus Chapter 11 reorganization. Journal of Finance, 61, 1253-1303.

Brouwer, M. (2006). Reorganization in U.S. and European bankruptcy law. European Journal of Law and Economics, 22, 5-20.

Campbell, S.V. (1996). Predicting bankruptcy reorganization for closely held firms. Accounting Horizons, 10, 12-25.

Corbière, F. \& Joly, P. (2007). A SAS macro for parametric and semiparametric mixture cure models. Computer Methods and Programs in Biomedicine, 85, 173-180.

Couwenberg, O. (2001). Survival rates in bankruptcy systems: overlooking the evidence. European Journal of Law and Economics, 12, 253-273. 
Denis, D.K., \& Rodgers, K.J. (2007). Chapter 11: duration, outcome, and post-reorganization performance. Journal of Financial and Quantitative Analysis, 42, 101-118.

Dewaelheyns, N., \& Van Hulle, C. (2006). Corporate failure prediction modelling: distorted by business groups' internal capital markets? Journal of Business Finance and Accounting, 33, 909-931.

Dewaelheyns, N., \& Van Hulle, C. (2008). Legal reform and aggregate small and micro business bankruptcy rates: evidence from the 1997 Belgian bankruptcy code. Small Business Economics, forthcoming.

Eisenberg, T., \& Tagashira, S. (1994). Should we abolish Chapter 11? The evidence from Japan. Journal of Legal Studies, 23, 111-157.

European Commission, Enterprise Directorate-General (2002). Bankruptcy and a fresh start: stigma on failure and legal consequences of bankruptcy.

European Commission, Enterprise Directorate-General (2003). BEST project on restructuring, bankruptcy and a fresh start: final report of the expert group.

Evans, J. (2003). The effect of discretionary actions on small firms' ability to survive Chapter 11 bankruptcy. Journal of Corporate Finance, 9, 115-128.

Franks, J.R., \& Torous, W.N. (1989). An empirical investigation of U.S. firms in reorganization. Journal of Finance, 44, 747-769.

Gertner, R., \& Scharfstein, D. (1991). A theory of workouts and the effects of reorganization law. Journal of Finance, 46, 1189-1222.

Hege, U. (2003). Workouts, court-supervised reorganization and the choice between private and public debt. Journal of Corporate Finance, 9, 233-269.

Helwege, J. (1999). How long do junk bonds spend in default? Journal of Finance, 54, 341357.

Helwege, J., \& Packer, F. (2003). Determinants of the choice of bankruptcy procedure in Japan. Journal of Financial Intermediation, 12, 96-120.

Hosmer, D.W., \& Lemeshow, S. (1999). Applied survival analysis: regression modeling of time to event data. New York: John Wiley and Sons.

Hotchkiss, E.S. (1995). Postbankruptcy performance and management turnover. Journal of Finance, 50, 3-21.

Kahl, M. (2002). Economic distress, financial distress, and dynamic liquidation. Journal of Finance, 57, 135-168.

Kaiser, K.M.J. (1996). European bankruptcy laws: implications for corporations facing financial distress. Financial Management, 25, 67-85.

Kiefer, N.M. (1988). Economic duration data and hazard functions. Journal of Economic Literature, 26, 646-679.

Kim, M., \& Kim, M. (1999). A note on the determinants of the outcomes of bankruptcy petitions: evidence from Korea. Journal of Business Finance and Accounting, 26, 9971011.

La Porta, R., Lopez de Silanes, F., Shleifer, A., \& Vishny, R. (1998). Law and finance. Journal of Political Economy, 106, 1113-1155.

Leyman, B., Schoors K.J.L. \& Coussement, P. (2008). The role of firm viability, creditor behavior and judicial discretion in the failure of distressed firms under court-supervised restructuring: evidence from Belgium. Universiteit Gent Working Paper 2008/509.

Li, K. (1999). Bayesian analysis of duration models: an application to Chapter 11 bankruptcy. Economics Letters, 63, 305-312.

LoPucki, L.M. \& Doherty J.W. (2007). Bankruptcy fire sales. Michigan Law Review, 106, 160.

Maksimovic, V., \& Phillips, G. (1998). Asset efficiency and reallocation decisions of bankrupt firms. Journal of Finance, 53, 1495-1532. 
Mooradian, R.M. (1994). The effect of bankruptcy protection on investment: Chapter 11 as a screening device. Journal of Finance, 49, 1403-1430.

Morrison, E.R. (2007). Bankruptcy decision-making: an empirical study of continuation bias in small business bankruptcies. Journal of Law and Economics, 50, 381-419.

Ohlson, J.A. (1980). Financial ratios and the probabilistic prediction of bankruptcy. Journal of Accounting Research, 18, 109-131.

Orbe, J., Ferreira, E., \& Núnẽz-Antón, V. (2002). Length of time spent in Chapter 11 bankruptcy: a censored partial regression model. Applied Economics, 34, 1949-1957.

Rajan, R.G. (1992). Insiders and outsiders: the choice between informed and arms-length debt. Journal of Finance, 47, 1367-1400.

Ravid, S.A., \& Sundgren, S. (1998). The comparative efficiency of small-firm bankruptcies: a study of the U.S. and Finnish bankruptcy codes. Financial Management, 27, 28-40.

Routledge, J., \& Gadenne, D. (2000). Financial distress, reorganization and corporate performance. Accounting and Finance, 40, 233-269.

Shleifer, A., \& Vishny, R.W. (1992). Liquidation values and debt capacity: a market equilibrium approach. Journal of Finance, 47, 1343-1366.

Sundgren, S. (1998). Does a reorganization law improve the efficiency of the insolvency law? The Finnish experience. European Journal of Law and Economics, 6, 177-198.

Tashjian, E., Lease, R.C., \& McConnell, J.J. (1996). Prepacks: an empirical analysis of prepackaged bankruptcies. Journal of Financial Economics, 40, 135-162.

Weiss, L. (1990). Bankruptcy resolution: direct costs and violation of priority of claims. Journal of Financial Economics, 27, 285-314.

White, M.J. (1994). Corporate bankruptcy as a filtering device: Chapter 11 reorganizations and out-of-court debt restructurings. Journal of Law, Economics \& Organization, 10, 268-295.

White, M.J. (1996). Survey evidence on business bankruptcy. In J.S. Bhandari, \& Weiss, L.A. (eds.), Corporate Bankruptcy: Economic and Legal Perspectives (pp.298-306).

World Bank (2001). Principles and guidelines for effective insolvency and creditor rights systems. 
Table 1

Belgian reorganization procedure: key statistics

\begin{tabular}{lccc}
\hline Panel A - Outcome of procedure & \multicolumn{3}{c}{ of } \\
\hline Cases started & $\begin{array}{c}\text { Number of } \\
\text { cases }\end{array}$ & $\begin{array}{c}\% \text { of } \\
\text { total cases } \\
\text { completed } \\
\text { cases }\end{array}$ \\
Exit as liquidation-type bankruptcy & 365 & & \\
Exit as voluntary liquidation & 260 & $71.2 \%$ & $79.0 \%$ \\
Exit as going concern & 29 & $7.9 \%$ & $8.8 \%$ \\
Not yet completed/unknown & 40 & $11.0 \%$ & $12.2 \%$ \\
\hline \hline
\end{tabular}

Panel B - Duration of completed procedures in months

\begin{tabular}{lccccc}
\hline & Average & Median & StDev & Min & Max \\
\hline All completed cases & 12.3 & 7.6 & 11.8 & 0.7 & 54.8 \\
Exit as liquidation-type bankruptcy & 9.4 & 6.6 & 8.4 & 0.7 & 51.2 \\
Exit as voluntary liquidation & 12.5 & 7.4 & 14.2 & 2.9 & 47.8 \\
Exit as going concern & 32.1 & 32.6 & 12.1 & 10.3 & 54.8 \\
\hline
\end{tabular}

Notes: Data on all reorganization procedures of limited liability stock corporations started between Jan $1^{\text {st }}$, 1998 and Dec 31 $1^{\text {st }}, 2003$. Procedure status as of January $31^{\text {st }}, 2005$. 
Table 2

Definitions of variables

\begin{tabular}{|c|c|}
\hline Size & Natural logarithm of total assets \\
\hline Profitability & (Operating income)/(total assets) \\
\hline Liquidity & Quick ratio: (current assets - inventory)/(current liabilities) \\
\hline Leverage & Total leverage ratio: (total liabilities)/(total assets) ${ }^{\text {(a) }}$ \\
\hline Asset specificity & (Fixed assets - land and buildings)/(total assets) ${ }^{(b)}$ \\
\hline Financial health & Altman (1993) Z”-score ${ }^{(c)}$ \\
\hline Uncertainty & $\begin{array}{l}\text { Industry average of the standard deviation of the operating profit } \\
\text { margin over the last } 3 \text { fiscal years (based on 3-digit Nace codes) }\end{array}$ \\
\hline Secured debt & (Secured debt)/(total assets) \\
\hline Industry sales growth & $\begin{array}{l}\text { Industry average of the annual sales growth over the last } 3 \text { fiscal } \\
\text { years (based on } 3 \text {-digit Nace codes) }\end{array}$ \\
\hline Industry profit margin & $\begin{array}{l}\text { Industry average of the operating profit margin for the last fiscal year } \\
\text { (based on } 3 \text { digit Nace codes) }\end{array}$ \\
\hline Group & $\begin{array}{l}\text { Dummy variable, equal to } 1 \text { if the filing company is part of a business } \\
\text { group, i.e. if it has an incorporated owner which controls at least } 50 \% \\
\text { of shares (directly or indirectly) or if the comments to the financial } \\
\text { statements show intra-group ties }\end{array}$ \\
\hline Cases per judge & $\begin{array}{l}\text { (Number of reorganization cases handled in the judicial district } \\
\text { during the sample period)/(number of full time commercial court } \\
\text { judges in the judicial district) }\end{array}$ \\
\hline Region & $\begin{array}{l}\text { Dummy variable, equal to } 1 \text { if the case is handled by a court in a } \\
\text { district with an average unemployment rate higher than the national } \\
\text { median }\end{array}$ \\
\hline
\end{tabular}

(a) Because in a bankruptcy procedure all claimants are important, following Hotchkiss (1995) and Denis and Rodgers (2007), we include all liabilities (i.e. both interest bearing and non-interest bearing) in our leverage proxy instead of, for instance, including only financial debt.

(b) Note that we prefer asset specificity over a standard tangibility ratio because earlier research has shown that the relationship between tangibility and reorganization chances is not clear-cut. Although availability of collateral helps to obtain credit, secured creditors are more likely to push for liquidation and to oppose a reorganization plan when the company falls on hard times (Bergström et al., 2002).

(c) The Z"-score weighs four financial ratios: EBIT/(total assets), (book value of equity)/(total liabilities), (working capital)/(total assets) and (retained earnings)/(total assets). Higher Z"-scores indicate stronger financial health. 
Table 3

Sample characteristics and summary statistics

Panel A - Sample size distribution

\begin{tabular}{lc}
\hline Total assets & $\%$ of sample \\
\hline$<500,000$ EUR & $20.9 \%$ \\
$500,000-2,500,000$ EUR & $46.8 \%$ \\
$2,500,000-10,000,000$ EUR & $24.7 \%$ \\
$>10,000,000$ EUR & $7.6 \%$ \\
& \\
Mean & 4.5 million EUR \\
Median & 1.3 million EUR \\
\hline
\end{tabular}

Panel B - Sample industry distribution

\begin{tabular}{lc}
\hline Industry & $\%$ of sample \\
\hline Manufacturing & $28.5 \%$ \\
Construction & $10.8 \%$ \\
Trade (wholesale \& retail) & $28.5 \%$ \\
Business services & $19.6 \%$ \\
Other & $12.7 \%$ \\
\hline
\end{tabular}

Panel C - Explanatory variables: summary statistics

\begin{tabular}{lccc}
\hline Variable & Median & Mean & StDev \\
\hline Size & 7.2233 & 7.2903 & 1.2680 \\
Profitability & -0.0652 & -0.1373 & 0.2004 \\
Liquidity & 0.7965 & 0.7855 & 0.3985 \\
Leverage & 0.9640 & 1.0467 & 0.3309 \\
Asset specificity & 0.0271 & 0.0902 & 0.1299 \\
Financial health & -2.1776 & -4.0262 & 6.4900 \\
Group financial health $^{(a)}$ & -0.3751 & -0.3967 & 3.1474 \\
Uncertainty $_{\text {Secured debt }}$ & 0.0608 & 0.0676 & 0.0235 \\
Industry sales growth & 0.0000 & 0.1507 & 0.2535 \\
Industry profit margin & 0.0755 & 0.0751 & 0.0390 \\
Group & 0.1151 & 0.1189 & 0.0297 \\
Cases per judge & - & 0.2468 & - \\
Region & 4.0000 & 4.9916 & 3.0509 \\
\hline
\end{tabular}

Note: See Table 2 for definition of variables.

(a) Statistics for the group member companies only. 
Table 4

Determinants of time spent in reorganization procedure before transfer to liquidation-type bankruptcy

\begin{tabular}{|c|c|c|c|c|c|c|c|}
\hline & (A) & (B) & $\left(\mathrm{B}^{\prime}\right)$ & (C) & $\left(C^{\prime}\right)$ & (D) & (D’) \\
\hline Size & $\begin{array}{r}-0.0238 \\
(0.193)\end{array}$ & $\begin{array}{r}-0.0282 \\
(0.315)\end{array}$ & $\begin{array}{r}-0.0463 \\
(0.718)\end{array}$ & $\begin{array}{r}-0.0263 \\
(0.259)\end{array}$ & $\begin{array}{c}-0.0400 \\
(0.543)\end{array}$ & $\begin{array}{r}-0.0372 \\
(0.417)\end{array}$ & $\begin{array}{r}-0.0342 \\
(0.396)\end{array}$ \\
\hline Profitability & $\begin{array}{l}0.2227 \\
(0.313)\end{array}$ & $\begin{array}{l}-0.0282 \\
(0.157)\end{array}$ & $\begin{array}{l}-0.0311 \\
(0.005)\end{array}$ & $\begin{array}{l}-0.0983 \\
(0.053)\end{array}$ & $\begin{array}{l}0.0297 \\
(0.005)\end{array}$ & $\begin{array}{l}-0.1752 \\
(0.167)\end{array}$ & $\begin{array}{l}-0.0835 \\
(0.0386)\end{array}$ \\
\hline Liquidity & $\begin{array}{l}0.0517 \\
(0.044)\end{array}$ & $\begin{array}{l}0.2409 \\
(1.170)\end{array}$ & $\begin{array}{l}0.1962 \\
(0.621)\end{array}$ & $\begin{array}{l}0.2368 \\
(1.103)\end{array}$ & $\begin{array}{l}0.2176 \\
(0.782)\end{array}$ & $\begin{array}{l}0.0362 \\
(0.023)\end{array}$ & $\begin{array}{l}0.0241 \\
(0.010)\end{array}$ \\
\hline Leverage & $\begin{array}{l}0.3377 \\
(1.736)\end{array}$ & $\begin{array}{c}0.4885^{*} \\
(3.404)\end{array}$ & $\begin{array}{l}0.4086 \\
(2.300)\end{array}$ & $\begin{array}{c}0.4930 * \\
(3.478)\end{array}$ & $\begin{array}{l}0.4377 \\
(2.640)\end{array}$ & $\begin{array}{l}0.2964 \\
(1.289)\end{array}$ & $\begin{array}{l}0.2877 \\
(1.222)\end{array}$ \\
\hline Asset specificity & $\begin{array}{c}0.9772 * \\
(2.736)\end{array}$ & $\begin{array}{c}1.3999^{* *} \\
(5.615)\end{array}$ & $\begin{array}{c}1.2396^{*} \\
(3.680)\end{array}$ & $\begin{array}{c}1.4294 * * \\
(5.744)\end{array}$ & $\begin{array}{c}1.2927 * * \\
(4.073)\end{array}$ & $\begin{array}{c}1.1918^{*} \\
(3.584)\end{array}$ & $\begin{array}{c}1.1885^{*} \\
(3.590)\end{array}$ \\
\hline Group & - & $\begin{array}{c}-0.5326^{* * *} \\
(9.417)\end{array}$ & $\begin{array}{c}-0.5258 * * * \\
(7.625)\end{array}$ & $\begin{array}{c}-0.6311 * * * \\
(12.668)\end{array}$ & $\begin{array}{c}-0.5323 * * * \\
(8.044)\end{array}$ & $\begin{array}{c}-0.4667 * * * \\
(6.547)\end{array}$ & $\begin{array}{c}-0.4719 * * * \\
\quad(6.838)\end{array}$ \\
\hline Cases per judge & - & $\begin{array}{r}-0.0384 \\
(2.280)\end{array}$ & $\begin{array}{r}-0.0301 \\
(1.124)\end{array}$ & $\begin{array}{r}-0.0385 \\
(2.282)\end{array}$ & $\begin{array}{r}-0.0248 \\
(0.771)\end{array}$ & $\begin{array}{c}-0.0447^{*} \\
(2.694)\end{array}$ & $\begin{array}{r}-0.0440 \\
(2.613)\end{array}$ \\
\hline Region & - & $\begin{array}{l}0.1779 \\
(0.125)\end{array}$ & $\begin{array}{l}0.1175 \\
(0.426)\end{array}$ & $\begin{array}{l}0.1551 \\
(0.924)\end{array}$ & $\begin{array}{l}0.0967 \\
(0.298)\end{array}$ & $\begin{array}{l}0.2175 \\
(1.697)\end{array}$ & $\begin{array}{l}0.2002 \\
(1.449)\end{array}$ \\
\hline Uncertainty & - & $\begin{array}{c}-7.5185 * * * \\
(6.437)\end{array}$ & $\begin{array}{c}-7.6987 * * * \\
(5.660)\end{array}$ & $\begin{array}{c}-11.9080 * * * \\
(14.497)\end{array}$ & $\begin{array}{c}-14.4514 * * * \\
\quad(10.568)\end{array}$ & $\begin{array}{c}-9.3810 * * * \\
(8.257)\end{array}$ & $\begin{array}{c}-8.3210^{* * * *} \\
\quad(7.102)\end{array}$ \\
\hline Industry sales growth & - & $\begin{array}{c}5.5916^{* * *} \\
(16.282)\end{array}$ & - & - & - & - & - \\
\hline Industry profit margin & - & - & $\begin{array}{l}3.7544 \\
(2.573)\end{array}$ & - & - & - & - \\
\hline $\begin{array}{l}\text { Uncertainty } \times \\
\text { Industry sales growth }\end{array}$ & - & - & - & $\begin{array}{c}62.5683 * * * \\
\quad(13.407)\end{array}$ & - & - & - \\
\hline $\begin{array}{l}\text { Uncertainty } \times \\
\text { Industry profit margin }\end{array}$ & - & - & - & - & $\begin{array}{c}62.1363 * * \\
(4.337)\end{array}$ & - & - \\
\hline Secured debt & - & - & - & - & - & $\begin{array}{c}-0.4325 * \\
(3.229)\end{array}$ & - \\
\hline $\begin{array}{l}\text { Uncertainty } \times \\
\text { Secured debt }\end{array}$ & - & - & - & - & - & - & $\begin{array}{c}-7.5339 * \\
(3.581)\end{array}$ \\
\hline Intercept & 1.9282 & 1.6475 & 1.9138 & 2.0567 & 2.2248 & 2.7401 & 2.6876 \\
\hline Scale & 0.6624 & 0.5775 & 0.6185 & 0.5825 & 0.6115 & 0.6095 & 0.6084 \\
\hline Shape & 1.5097 & 1.7315 & 1.6168 & 1.7166 & 1.6352 & 1.6408 & 1.6438 \\
\hline Industry dummies & No & Yes & Yes & Yes & Yes & Yes & Yes \\
\hline Log likelihood & -142.1 & -128.0 & -133.7 & -129.2 & -132.9 & -133.0 & -132.8 \\
\hline Likelihood ratio test & 5.0 & $33.3 * * *$ & $21.8^{*}$ & $30.9 * * *$ & $23.5 * *$ & $23.4 * *$ & $23.7 * *$ \\
\hline
\end{tabular}

Notes: Accelerated Failure Time Models (Weibull distributed); Wald test statistics ( $\chi^{2}$ distributed) in parentheses; variables as defined in Table $2 ; * * *$ denotes significance at the $1 \%$ level; $* *$ denotes significance at the $5 \%$ level; $*$ denotes significance at the $10 \%$ level 
Table 5

Determinants of time spent in reorganization procedure before transfer to liquidation-type bankruptcy (continued)

\begin{tabular}{|c|c|c|c|c|}
\hline & $(\mathrm{E})$ & $(\mathrm{F})$ & (G) & $(\mathrm{H})$ \\
\hline Size & $\begin{array}{c}-0.0260 \\
(0.232)\end{array}$ & $\begin{array}{c}-0.0330 \\
(0.428)\end{array}$ & - & $\begin{array}{l}0.0089 \\
(0.030)\end{array}$ \\
\hline Profitability & $\begin{array}{r}-0.4162 \\
(0.809)\end{array}$ & $\begin{array}{c}-0.3476 \\
(0.672)\end{array}$ & - & $\begin{array}{r}-0.4227 \\
(0.977)\end{array}$ \\
\hline Liquidity & $\begin{array}{l}0.1113 \\
(0.290)\end{array}$ & $\begin{array}{l}0.2536 \\
(1.321)\end{array}$ & - & $\begin{array}{l}0.2269 \\
(1.107)\end{array}$ \\
\hline Leverage & $\begin{array}{l}0.3146 \\
(1.464)\end{array}$ & $\begin{array}{c}0.4174 * \\
(2.774)\end{array}$ & - & $\begin{array}{c}0.4139 * \\
(2.726)\end{array}$ \\
\hline Asset specificity & $\begin{array}{c}1.1885^{*} \\
(3.635)\end{array}$ & $\begin{array}{c}1.2744^{* *} \\
(4.501)\end{array}$ & - & $\begin{array}{c}1.2882^{* *} \\
(4.503)\end{array}$ \\
\hline Financial health & - & - & $\begin{array}{c}-0.0304^{* * *} * \\
(10.718)\end{array}$ & - \\
\hline Group & $\begin{array}{c}-0.4432 * * \\
(6.327)\end{array}$ & $\begin{array}{c}-0.6739 * * * \\
(14.887)\end{array}$ & $\begin{array}{c}-0.6695 * * * \\
(14.148)\end{array}$ & - \\
\hline Financially distressed group & - & - & - & $\begin{array}{c}-0.6920 * * \\
(5.936)\end{array}$ \\
\hline Non-financially distressed group & - & - & - & $\begin{array}{c}-1.3404 * * * \\
(13.449)\end{array}$ \\
\hline Cases per judge & $\begin{array}{c}-0.0461 * \\
(2.925)\end{array}$ & $\begin{array}{c}-0.0579 * * \\
(5.162)\end{array}$ & $\begin{array}{c}-0.0497 * \\
(3.621)\end{array}$ & $\begin{array}{c}-0.0492 * \\
(3.662)\end{array}$ \\
\hline Region & $\begin{array}{l}0.2319 \\
(1.947)\end{array}$ & $\begin{array}{l}0.2150 \\
(1.830)\end{array}$ & $\begin{array}{l}0.2305 \\
(2.190)\end{array}$ & $\begin{array}{l}0.1845 \\
(1.340)\end{array}$ \\
\hline Uncertainty & $\begin{array}{c}-9.0940 * * * \\
(8.572)\end{array}$ & - & - & - \\
\hline $\begin{array}{l}\text { Uncertainty } \times \text { Secured debt } \\
\times \text { Normal or strong industry outlook }\end{array}$ & $\begin{array}{r}-3.8162 \\
(0.664)\end{array}$ & - & - & - \\
\hline $\begin{array}{l}\text { Uncertainty } \times \text { Secured debt } \\
\times \text { Weak industry outlook }\end{array}$ & $\begin{array}{l}-18.4439 * * * \\
\quad(7.629)\end{array}$ & - & - & - \\
\hline $\begin{array}{l}\text { Uncertainty } \times \\
\text { Normal or strong industry outlook }\end{array}$ & - & $\begin{array}{r}-3.9976 \\
(1.551)\end{array}$ & $\begin{array}{r}-4.8273 \\
(2.333)\end{array}$ & $\begin{array}{r}-6.1771^{*} \\
(3.568)\end{array}$ \\
\hline $\begin{array}{l}\text { Uncertainty } \times \\
\text { Weak industry outlook }\end{array}$ & - & $\begin{array}{l}-11.6672 * * * \\
\quad(14.158)\end{array}$ & $\begin{array}{l}-12.2958 * * * \\
\quad(16.543)\end{array}$ & $\begin{array}{l}-13.2609 * * * \\
\quad(17.485)\end{array}$ \\
\hline Intercept & 2.5439 & 2.1200 & 2.5884 & 2.0525 \\
\hline Scale & 0.6022 & 0.5762 & 0.5832 & 0.5768 \\
\hline Shape & 1.6606 & 1.7354 & 1.7146 & 1.7338 \\
\hline Industry dummies & Yes & Yes & Yes & Yes \\
\hline Log likelihood & -131.2 & -127.7 & -128.4 & -127.5 \\
\hline Likelihood ratio test & $27.0 * *$ & $33.9^{* * *}$ & $32.5^{* * *}$ & $34.3^{* * *}$ \\
\hline
\end{tabular}

Notes: Accelerated Failure Time Models (Weibull distributed); Wald test statistics ( $\chi^{2}$ distributed) in parentheses; variables as defined in Table $2 ; * * *$ denotes significance at the $1 \%$ level; $* *$ denotes significance at the $5 \%$ level; * denotes significance at the $10 \%$ level 
Table 6

Determinants of time spent in reorganization procedure (all cases)

\begin{tabular}{|c|c|c|c|c|}
\hline & (I) & $(\mathrm{J})$ & $(\mathrm{K})$ & $(\mathrm{L})$ \\
\hline Size & $\begin{array}{r}-0.0798 \\
(0.866)\end{array}$ & $\begin{array}{r}-0.0417 \\
(0.479)\end{array}$ & - & $\begin{array}{r}-0.0400 \\
(0.424)\end{array}$ \\
\hline Profitability & $\begin{array}{r}-0.8245 \\
(1.116)\end{array}$ & $\begin{array}{r}-1.1742 \\
(1.610)\end{array}$ & - & $\begin{array}{r}-0.6686 \\
(0.907)\end{array}$ \\
\hline Liquidity & $\begin{array}{r}-0.1079 \\
(0.306)\end{array}$ & $\begin{array}{r}-0.0355 \\
(0.339)\end{array}$ & - & $\begin{array}{r}-0.0959 \\
(0.246)\end{array}$ \\
\hline Leverage & $\begin{array}{r}-0.0571 \\
(0.124)\end{array}$ & $\begin{array}{r}-0.1124 \\
(0.245)\end{array}$ & - & $\begin{array}{l}0.0009 \\
(0.002)\end{array}$ \\
\hline Asset specificity & $\begin{array}{l}1.2252 \\
(1.289)\end{array}$ & $\begin{array}{l}0.2619 \\
(0.301)\end{array}$ & - & $\begin{array}{l}0.7381 \\
(0.706)\end{array}$ \\
\hline Financial health & - & - & $\begin{array}{l}-0.0394 * * * \\
(2.596)\end{array}$ & - \\
\hline Group & $\begin{array}{c}-0.4874 * \\
(1.846)\end{array}$ & $\begin{array}{c}-0.9641 * * * \\
(3.754)\end{array}$ & $\begin{array}{c}-0.9969 * * * \\
\quad(3.969)\end{array}$ & - \\
\hline Financially distressed group & - & - & - & $\begin{array}{c}-1.0894 * * \\
(2.487)\end{array}$ \\
\hline Non-financially distressed group & - & - & - & $\begin{array}{c}-1.5587 * * * \\
(2.778)\end{array}$ \\
\hline Cases per judge & $\begin{array}{l}-0.0585 \\
(1.269)\end{array}$ & $\begin{array}{c}-0.0760 \\
(1.648\end{array}$ & $\begin{array}{c}-0.0998 * * \\
(2.125)\end{array}$ & $\begin{array}{r}-0.0408 \\
(0.900)\end{array}$ \\
\hline Region & $\begin{array}{l}0.2042 \\
(0.763)\end{array}$ & $\begin{array}{l}0.1814 \\
(0.690)\end{array}$ & $\begin{array}{l}0.3277 \\
(1.117)\end{array}$ & $\begin{array}{r}-0.0258 \\
(0.096)\end{array}$ \\
\hline Uncertainty & $\begin{array}{l}-13.3210 * * * \\
(2.727)\end{array}$ & - & - & - \\
\hline $\begin{array}{l}\text { Uncertainty } \times \text { Secured debt } \\
\times \text { Normal or strong industry outlook }\end{array}$ & $\begin{array}{r}-4.8460 \\
(0.700)\end{array}$ & - & - & - \\
\hline $\begin{array}{l}\text { Uncertainty } \times \text { Secured debt } \\
\times \text { Weak industry outlook }\end{array}$ & $\begin{array}{l}-31.6868 * * * \\
\quad(2.866)\end{array}$ & - & - & - \\
\hline $\begin{array}{l}\text { Uncertainty } \times \\
\text { Normal or strong industry outlook }\end{array}$ & - & $\begin{array}{r}-6.9977 \\
(1.385)\end{array}$ & $\begin{array}{r}-6.0113 \\
(1.222)\end{array}$ & $\begin{array}{r}-6.9576 \\
(1.295)\end{array}$ \\
\hline $\begin{array}{l}\text { Uncertainty } \times \\
\text { Weak industry outlook }\end{array}$ & - & $\begin{array}{l}-18.8456^{* * * *} \\
\quad(3.568)\end{array}$ & $\begin{array}{l}-18.1802 * * * \\
\quad(3.609)\end{array}$ & $\begin{array}{l}-16.5909 * * * \\
(3.099)\end{array}$ \\
\hline Scale & 0.3675 & 0.3600 & 0.3574 & 0.3494 \\
\hline Shape & 1.3203 & 1.1066 & 0.9704 & 1.1141 \\
\hline Industry dummies & Yes & Yes & Yes & Yes \\
\hline Log likelihood & -191.2 & -187.9 & -191.0 & -185.7 \\
\hline Likelihood ratio test & $39.6 * *$ & $46.2 * * *$ & $39.9 * * *$ & $50.6 * * *$ \\
\hline
\end{tabular}

